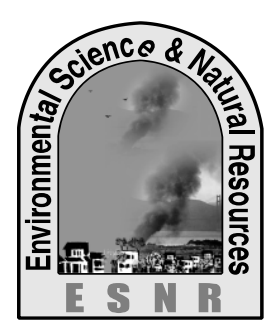

\title{
Comparison between Vermicompost and Conventional Aerobic Compost Produced from Municipal Organic Solid Waste Used in Amaranthus viridis Production
}

\author{
M. S. Islam ${ }^{1 *}$, M. Hasan ${ }^{1}$, M. M. Rahman ${ }^{1}$, M. N. Uddin ${ }^{2}$ and M. H. Kabir ${ }^{1}$
}

${ }^{1}$ Department of Environmental Science and Resource Management, Mawlana Bhashani Science and Technology University, Tangail-1902, Bangladesh

${ }^{2}$ Horticultural Research Centre, Bangladesh Agricultural Research Institute, Gazipur-1701, Bangladesh

*Corresponding author: islammstazu@yahoo.com

\begin{abstract}
The study was conducted to determine the performance of vermicompost and conventional aerobic compost produced from municipal organic solid waste used in Amaranthus viridis production during the period from October 2014 to June 2015 at the Horticulture Research Centre of the Bangladesh Agriculture Research Institute, Gazipur, Bangladesh. In this study, three compost varieties (vermicompost, conventional aerobic compost, combination of vermicompost and conventional compost) and three levels of compost treatments $\left(0,100\right.$ and $\left.150 \mathrm{~g} / \mathrm{m}^{2}\right)$ with three replications were applied. The plots were arranged in randomized complete block design. Vermicompost was prepared by using Eisenia fetida. Different composts (vermicompost and conventional aerobic compost) and plant sample were taken first for chemical and physical analysis to find out the effect of these composts on the growth of amaranth. The result of the study showed that different compost varieties significantly affected the chlorophyll content, dry matter content, height per plant, numbers of leaves, weight per plant, nitrogen, calcium, magnesium, potassium, total phosphorus positively in favour of vermicompost application and sulphur content, sodium, moisture content in conventional aerobic compost application. Vermicompost application showed higher result for growth and yield indices and nutrient content compared with conventional aerobic compost.
\end{abstract}

Key words: Conventional aerobic compost, Nutrient, Solid waste, Vermicompost and Yield

\section{Introduction}

Soil fertility is declining over large parts of the world, particularly the developing countries. Use of chemical fertilizers, intensive and continuous cropping without replenishing the nutrient component of soils, deforestation and clearance of vegetation accelerates the depletion of soil organic matter and impairment of physical and chemical properties of soil (Ayoub, 1999). The organic matter of more than $50 \%$ of cultivated soils in Bangladesh is said to be below the critical level of $1.5 \%$ and still declining at an alarming rate (Karim, 1997). Tropical soils are deficient in all necessary plant nutrients. The use of organic inputs has potentiality for improving soil productivity and crop yield. Moreover organic farming is appreciated by vegetable consumers as it enhances quality of the product. In natures laboratory there are a number of organisms that have the ability to convert organic waste into valuable resources which contains plant nutrients and organic matter that are essential for maintaining soil productivity (Devi et al., 1998). Species such as earthworms and termites produce biogenic structures and thus modify the physicochemical environment of other organisms. Earthworms are considered to be key biological agents in consuming, fragmenting, and intimately mixing organic matter with soil mineral particles to form water stable aggregates and consequently, modify soil hydrodynamic and many

\section{Materials and Methods}

\section{Study area}

The study was carried out at the research field of Horticulture Research Centre (HRC) of Bangladesh Agriculture Research Institute (BARI), Joydebpur, Gazipur for a period of 10 months from October 2014 to June 2015 is located on $23.98453^{\circ} \mathrm{N}$ latitudes and $90.40431^{\circ} \mathrm{E}$ longitudes, $100 \mathrm{~m}$ above mean sea level which is geographically a part of the pleistocene other desirable characteristics (Blanchart et al., 1999). Vermicomposting is a simple biotechnological process of composting, in which certain species of earthworms are used to enhance the process of waste conversion and produce a better end product. Vermicomposting using earthworms as natural bioreactors for effective recycling of organic wastes is an environmentally acceptable which defined also as a low cost technology system (Hand et al., 1988b).

Vermicompost has been enriched by beneficial microbes to increase the fertilizer value and reduce the dose of application. As a bioinoculant, vermicompost increased nitrogen and phosphorous availability by enhancing biological nitrogen fixation and phosphorous solubilisation (Padmavathiamma et al., 2008). In conventional aerobic composting where biological aerobic transformation of an organic by product takes place and results into different organic product that can be added to the soil without detrimental effects of crop growth (Baca et al., 1992). These composts provide all nutrients in readily available forms and also enhances uptake of nutrients by plants and plays a major role in improving growth and yield of different field crops (Sreenivas et al., 2000). The study was conducted to determine the performance of vermicompost and conventional aerobic compost in the growth, yield and nutrient content of Amaranthus viridis known as red amaranth.

terrace, popularly known as Madhupur tract. The area characterized by high temperature, high humidity and heavy rainfall. Average normal rainfall is $179 \mathrm{~mm}$, average humidity is $80 \%$ and average maximum temperature is $30.57^{\circ} \mathrm{C}$ and average minimum temperature is $21.93^{\circ} \mathrm{C}$.

\section{Experimental procedure}

In the present investigation vermicompost (VC) and conventional aerobic compost (CC) were prepared from 
municipal organic wastes where vermicompost used red worms (Eisenia fatida). Cow dung and bedding materials such as coconut fibre, straw, shredded papers were used for vermicompost preparation. Rice husk, grass cutting and kitchen wastes were used for conventional aerobic compost preparation. The Amaranthus viridis (BARI-2) was taken as experimental plant. A land of $1.8 \mathrm{~m}^{2}(16.9 \mathrm{~m} \times 5.6 \mathrm{~m})$ was used for experimental field where cow dung was added and then ploughed for three times and the soil was leveled properly. At the same time, the weeds, stubble and crop residues were removed from the plot. The experimental plot was divided into 27 plots with three replications of nine treatments, the distance between two adjacent plots was $30 \mathrm{~cm}$ and one replication to another replication was $50 \mathrm{~cm}$ which was used as water draining. The size of each unit plot was $1.5 \mathrm{~m} \times 1.2 \mathrm{~m}$. The different doses of vermicompost, conventional aerobic compost and combination of both composts $(\mathrm{VC}+\mathrm{CC})$ were applied in the treatments as the sources of organic fertilizer. Well prepared vermicompost and conventional aerobic compost manure were incorporated in the plots as per treatment $\left(\mathrm{T}_{1}=0 \mathrm{gm}^{-2}\right.$, $\mathrm{T}_{2}=100 \mathrm{gm}^{-2}, \mathrm{~T}_{3}=150 \mathrm{gm}^{-2}$ ) at 5 days before showing seeds and then they were mixed thoroughly with the soil. Seeds of amaranth (Amaranthus viridis) were collected from Bangladesh Agriculture Research Institute, Joydebpur, Gazipur. The seeds were sown in four rows and ten columns with distance between two rows and two columns were $30 \mathrm{~cm}$ and $15 \mathrm{~cm}$ respectively. Seeds were started to germinate $3^{\text {rd }}$ day of sowing. On the $5^{\text {th }}$ days maximum seeds were germinated. After the establishment of seedlings, careful and routine observation was made daily. Various intercultural operations viz. irrigation and drainage, gap filling, weeding, top dressing were accomplished for better growth and development of red amaranth seedlings. General observation was made every day to notice the growth of the amaranth. To evaluate plant nutrient, growth and yield of plant, crop was harvested 48 days after germination.

\section{Sample collection}

Vermicompost and conventional aerobic compost samples were collected from the upper layer of matured vermicompost and conventional aerobic compost. For chemical analysis of the soil from the experimental field, soil sample were taken from each plot at $0-15 \mathrm{~cm}$ depth by an auger. For analysis of crop plants, a few representative plants were picked randomly from each plot.

\section{Data collection}

Two types of composts and soil of the study plot were taken and analyzed. The collected samples were then air-dried, and ground to pass through a $2 \mathrm{~mm}$ sieve and stored in a clean plastic container for chemical analysis. The number of leaves per plant was count from representative plant of each plot. Data were recorded as the average of three plants selected at random from the inner rows of each plot starting from 30 to 60 days after germination (DAG) at 15 days interval. Three plants were randomly selected from each plot of the experiment. Height was measured in centimeter and weight was measured in gram and the data was averaged for each plot. Chlorophyll content or soil-plant analysis development (SPAD) value was measured by SPAD- 502 meter. Healthy, fresh and mature leaves were selected for measuring SPAD value. Samples were taken two times and then average value was calculated. Immediately after harvest, sample plants were cut into small pieces and were weighed by electric balance. The samples were then placed in an oven maintained at $100^{\circ} \mathrm{C}$ for 72 hours. Then final weights were taken by electric balance. Moisture accumulation percentage was computed as,

$$
\text { Moisture content }(\%)=\frac{\text { Fresh weight-Oven dry weight }}{\text { Fresh weight }} \times 100
$$

Edible plant part of amaranth was collected as plant sample for chemical analysis such as nitrogen, calcium, magnesium, potassium, sodium, total phosphorus and sulphur content for determination of the nutrient difference between vermicompost applied crop and conventional aerobic compost applied crop. Plant sample collection and analysis took two months (April to June) of 2015. Sliced thin pieces of plants were put into an envelope and placed into oven and dried at $100^{\circ} \mathrm{C}$ for 72 hours. The sample was then transferred into desiccators and allowed to cool down to room temperature and finally weighted. The dry matter was calculated by using following formula:

\section{$\%$ Dry matter content $=100$ - moisture content}

\section{Chemical analysis}

The seven types of nutrient content were analyzed from soil, vermicompost, conventional aerobic compost and plant sample for evaluating effectiveness of vermicompost compared with conventional aerobic compost. Soil, compost and plant nutrients were analyzed in different kinds of methods (Table 1). 
Table 1. Nutrients of soil, plants, vermicompost and conventional compost with their methods

\begin{tabular}{|c|c|c|c|}
\hline \multirow[t]{2}{*}{ Nutrient } & \multicolumn{3}{|c|}{ Methods } \\
\hline & Soil & Compost & Plant \\
\hline Total nitrogen & Kjeldhal & Kjeldhal & Kjeldhal \\
\hline Phosphorus & Bray and Kurtz & Bray and Kurtz & Di acid digestion \\
\hline Magnesium & $\mathrm{N}-\mathrm{NH}_{4} \mathrm{OAc}$ & $\mathrm{N}-\mathrm{NH}_{4} \mathrm{OAc}$ & $\mathrm{Na}_{2}$ EDTA \\
\hline Potassium & $\mathrm{N}-\mathrm{NH}_{4} \mathrm{OAc}$ & $\mathrm{N}-\mathrm{NH}_{4} \mathrm{OAc}$ & Flame Photometry \\
\hline Sulphur & $\mathrm{HNO}_{3}$ digestion & $\mathrm{HNO}_{3}$ digestion & Flame photometry \\
\hline Sodium & - & $\mathrm{N}-\mathrm{NH}_{4} \mathrm{OAc}$ & Di acid digestion \\
\hline
\end{tabular}

\section{Results and Discussion}

Soil of the experimental plot was analyzed where $\mathrm{Ca}$ content $0.227 \%$ was highest and total phosphorus content $0.002 \%$ was lowest (Table 2). From the chemical analysis of vermicompost and conventional aerobic compost it was evident that $\mathrm{Mg}, \mathrm{Ca}, \mathrm{P}$ and $\mathrm{Na}$ content was superior in vermicompost rather than conventional aerobic compost. On the other hand $\mathrm{S}, \mathrm{k}$ and $\mathrm{N}$ content of conventional aerobic compost was higher than vermicompost (Table 3).

Table 2. Initial soil characteristics of the experimental field

$\begin{array}{lc}\text { Parameter } & \text { Nutrient value (\%) } \\ \text { Nitrogen } & 0.050 \\ \text { Magnesium } & 0.038 \\ \text { Calcium } & 0.227 \\ \text { Potassium } & 0.016 \\ \text { Total Phosphorus } & 0.002 \\ \text { Sulphur } & 0.007\end{array}$

\section{Chlorophyll content}

The highest chlorophyll content $(38.58 \%)$ was recorded at the day $15^{\text {th }}$ after germination in $\mathrm{T}_{3}$ of $\mathrm{VC}$ and the lowest $(30.15 \%)$ in $\mathrm{T}_{1}$ of CC (Table 3). It was observed that the chlorophyll content was gradually become superior from control treatment to increased does of every type of compost application. The chlorophyll content in all three control treatments was more or less identical. The results showed that in $\mathrm{T}_{2}$ of $\mathrm{VC}, \mathrm{CC}$ and $\mathrm{VC}+\mathrm{CC}$, leaf chlorophyll content was superior in $\mathrm{VC}+\mathrm{CC}$ than $\mathrm{VC}$ and $\mathrm{CC}$, where $\mathrm{VC}$ was superior than CC. In case of $\mathrm{T}_{3}$, leaf chlorophyll content in $\mathrm{VC}$ showed superior results than $\mathrm{VC}+\mathrm{CC}$ and $\mathrm{CC}$ treatments.

At $30^{\text {th }}$ day after germination the highest chlorophyll content $(35.00 \%)$ was observed in $\mathrm{T}_{3}$ of $\mathrm{VC}+\mathrm{CC}$ and lowest $(24.83 \%)$ in $\mathrm{T}_{1}$ of $\mathrm{VC}+\mathrm{CC}$. As like as $15^{\text {th }}$ day after germination observation there was gradual increase of chlorophyll content from control treatment to increase dose of every types of compost observed at $30^{\text {th }}$ day after germination. Chlorophyll content at $30^{\text {th }}$ day after germination became lower than $15^{\text {th }}$ day after germination which probably due to gradual reduction of plant nitrogen where chlorophyll gives an indirect estimation of the nutrient status because much of leaf nitrogen is incorporated in chlorophyll pigments (Filella et al., 1995). Another cause behind reduction of chlorophyll content would be physiological change of plant. Total chlorophyll in the leaves increased during the vegetative growth period, reaching a maximum close to beginning of flowering and panicle formation for both quinoa and amaranth, and then decreased during reproductive and senescence periods (Riccardi, 2014).

Table 3. Nutrient condition of vermicompost and conventional compost

\begin{tabular}{lcc}
\hline Parameters & Vermicompost $(\boldsymbol{\%})$ & Conventional compost $(\%)$ \\
\hline Nitrogen & 0.98 & 1.57 \\
Magnesium & 3.70 & 0.46 \\
Calcium & 4.46 & 0.24 \\
Potassium & 0.53 & 1.14 \\
Sodium & 0.09 & 0.085 \\
Total Phosphorus & 0.70 & 0.64 \\
Sulphur & 0.66 & 0.72 \\
\hline
\end{tabular}

\section{Moisture content}

The maximum moisture content $(90.98 \%)$ was found in amaranth at $10^{\text {th }}$ day after germination from $\mathrm{T}_{1}$ of $\mathrm{CC}$ and minimum value was found $(90.06 \%)$ from $\mathrm{T}_{2}$ of $\mathrm{VC}$ (Table 3 ). At $30^{\text {th }}$ day after germination the maximum value $(90.49 \%)$ was found in $\mathrm{T}_{1}$ of $\mathrm{CC}$ and minimum was $(89.84 \%)$ in $\mathrm{T}_{3}$ of $\mathrm{CC}$. It was indicated that all the treatments conserve less water except control. In case of $\mathrm{T}_{2}$ and $\mathrm{T}_{3}$, moisture content was highest in $\mathrm{CC}$ and lowest in $\mathrm{VC}$ with intermediate value in $\mathrm{VC}+\mathrm{CC}$. The result indicated less water content in $\mathrm{VC}$ than others which influenced crop yield as higher yield in $\mathrm{VC}$ than 
$\mathrm{VC}+\mathrm{CC}$ and CC. Similar result was also reported in a study where the conventional farming conserves more water than organic farming in red amaranth (Islam, 2006).

\section{Dry matter content}

The results at $10^{\text {th }}$ day after germination showed maximum dry matter content $(9.94 \%)$ in $\mathrm{T}_{2}$ of $\mathrm{VC}$ and minimum $(9.02 \%)$ in $\mathrm{T}_{1}$ of CC (Table 3$)$. At $30^{\text {th }}$ day after germination highest dry matter content $(10.16 \%)$ was observed in $\mathrm{T}_{3}$ of $\mathrm{CC}$ and lowest $(9.51 \%)$ was in $\mathrm{T}_{1}$ of CC. On an average the result indicated higher dry matter content in VC than others which influenced crop yield as higher yield in $\mathrm{VC}$ than $\mathrm{VC}+\mathrm{CC}$ and $\mathrm{CC}$. This was due to lower moisture content in $\mathrm{VC}$ than $\mathrm{VC}+\mathrm{CC}$ and CC. Higher dry matter means higher solid part of crop which is the indicator of yield.

\section{Plant height}

The highest individual plant height $(80 \mathrm{~cm})$ was recorded in $\mathrm{T}_{3}$ of $\mathrm{VC}+\mathrm{CC}$ and lowest $(27.66 \mathrm{~cm})$ in $\mathrm{T}_{2}$ of $\mathrm{VC}+\mathrm{CC}$ (Table 4). For $\mathrm{T}_{2}$, plant height was highest in $\mathrm{CC}$, lowest in $\mathrm{VC}+\mathrm{CC}$ and for $\mathrm{T}_{3}$, highest in $\mathrm{VC}+\mathrm{CC}$ and lowest in CC. But mean plant height for all treatment was highest in $\mathrm{VC}$ and lowest in $\mathrm{VC}+\mathrm{CC}$. This probably due to vermicompost improved the soil physical properties particularly soil porosity, structure, water holding capacity and supplied other plant growth promoting substances. Thus application of vermicompost significantly increased plant height for the improvement of soil physical properties by vermicompost application (Jahan et al., 2014).

Table 4. Chlorophyll, moisture and dry matter content of amaranth by variety of compost application at different day after germination

\begin{tabular}{|c|c|c|c|c|c|c|c|c|c|c|}
\hline \multirow[t]{3}{*}{ Parameter } & \multirow[t]{3}{*}{ DAG } & \multicolumn{9}{|c|}{ Compost $\left(\mathrm{gm}^{-2}\right)$} \\
\hline & & \multicolumn{3}{|c|}{$\mathrm{VC}$} & \multicolumn{3}{|c|}{$\mathrm{CC}$} & \multicolumn{3}{|c|}{$\mathrm{VC}+\mathrm{CC}$} \\
\hline & & 0 & 100 & 150 & 0 & 100 & 150 & 0 & 100 & 150 \\
\hline \multirow{2}{*}{ Chlorophyll (\%) } & 15 & 33.75 & 35.06 & 38.58 & 30.15 & 34.14 & 36.24 & 31.69 & 35.43 & 37.51 \\
\hline & 30 & 28.94 & 30.58 & 34.90 & 25.43 & 28.49 & 34.02 & 24.83 & 28.37 & 35.00 \\
\hline \multirow{2}{*}{$\begin{array}{l}\text { Moisture } \\
(\%)\end{array}$} & 10 & 90.43 & 90.06 & 90.38 & 90.98 & 90.21 & 90.93 & 90.87 & 90.62 & 90.69 \\
\hline & 30 & 90.14 & 89.86 & 90.00 & 90.49 & 90.20 & 89.84 & 90.38 & 90.22 & 90.07 \\
\hline \multirow{2}{*}{ Dry matter (\%) } & 10 & 9.57 & 9.94 & 9.62 & 9.02 & 9.79 & 9.07 & 9.13 & 9.38 & 9.31 \\
\hline & 30 & 9.86 & 10.14 & 10.00 & 9.51 & 9.80 & 10.16 & 9.62 & 9.78 & 9.93 \\
\hline
\end{tabular}

Note: $\mathrm{DAG}=$ Days after germination

\section{Weight per plant}

Highest weight per plant $(74.16 \mathrm{~g})$ was recorded from $\mathrm{T}_{3}$ of $\mathrm{VC}$ and lowest weight per plant $\left(25.33 \mathrm{~g}\right.$ ) from $\mathrm{T}_{1}$ of $\mathrm{VC}+\mathrm{CC}$ (Table 4). For every compost variety, $\mathrm{T}_{3}$ showed significant difference as it higher than $\mathrm{T}_{1}$ and $\mathrm{T}_{2}$. With the increase of compost level, weight per plant was increased. The study showed that weight per plant was highest for vermicompost in $\mathrm{T}_{2}$ and $\mathrm{T}_{3}$ compared with conventional compost application alone or combination of vermicompost and conventional compost. This might be due to plant growth regulators and other plant growth influencing materials produced by microorganisms are present in vermicompost (Grappelli et al., 1987). This also can be due to higher leaf chlorophyll content in vermicompost applied plants which encourage increase of photosynthesis rate that results higher growth. The chlorophyll content is linked directly to photosynthetic potential and primary production (Curran et al., 1990).

\section{Number of leaves per plant}

The highest number of leaves per plant (19.33) was recorded from $\mathrm{T}_{3}$ of $\mathrm{VC}$ and lowest number of leaves per plant (13.0) was recorded from $\mathrm{T}_{1}$ of CC (Table 4). The study obtained that vermicompost application at $\mathrm{T}_{2}$ and $\mathrm{T}_{3}$ treatment showed higher number of leaves compared with conventional compost or combination of vermicompost and conventional compost which encourage enhancement of photosynthesis rate that helps to plant growth of vermicompost treated crop. Similar result was found that average number of leaves of amaranthus species enhanced by vermicompost application (Uma and Malathi, 2009).

\section{Nitrogen content}

Highest nitrogen content $(0.72 \%)$ was recorded in $\mathrm{T}_{3}$ of $\mathrm{VC}$ and lowest $(0.23 \%)$ was recorded from $\mathrm{T}_{1}$ of $\mathrm{VC}$ and $\mathrm{CC}$ (Table 6). In case of $\mathrm{T}_{2}$ and $\mathrm{T}_{3}$, highest nitrogen content was found in VC where $\mathrm{T}_{1}$ of all three compost varieties was identical. The study showed that, nitrogen uptake by amaranth was highest in vermicompost application where just conventional compost application showed lowest nitrogen uptake. This might be due to vermicompost hold more available nutrients over longer periods (Ndegwa and Thompson, 2001). In a similar study on amaranth showed that vermicompost treated crops obtained higher nitrogen content than compost and control (Hossain, 2007). Enhanced nitrogen content encourages increased growth and yield of crop. Nitrogen is the main yield factor and considered as the characteristic constituent of functional plasma, an integral part of chlorophyll molecules, proteins, amino acids, nucleic acids (RNA and DNA), nucleotides, phosphotides, alkaloids, enzymes, coenzymes, hormones, and vitamins (Castellanos et al., 2000). 
Table 5. Physical parameters of amaranth by different compost application

\begin{tabular}{lccccccccc}
\hline Parameter & \multicolumn{1}{c}{ Compost $\left(\mathbf{g} / \mathbf{m}^{2}\right)$} \\
\cline { 2 - 10 } & \multicolumn{3}{c}{ VC } & \multicolumn{1}{c}{ CC } & \multicolumn{4}{c}{ VC+CC } \\
\cline { 2 - 10 } & 0 & 100 & 150 & 0 & 100 & 150 & 0 & 100 & 150 \\
Plant height (cm) & 38.73 & 56.50 & 65.30 & 38.13 & 74.50 & 46.63 & 37.86 & 27.66 & 80.00 \\
Weight per plant (g) & 27.80 & 63.33 & 74.16 & 30.63 & 45.43 & 53.33 & 25.33 & 50.67 & 61.33 \\
No. of leaves per plant & 13.33 & 18.33 & 19.33 & 13.00 & 16.00 & 18.67 & 16.00 & 14.00 & 17.00 \\
\hline
\end{tabular}

\section{Calcium content}

The highest amount of calcium content (1.683\%) was recorded from $\mathrm{T}_{3}$ of $\mathrm{VC}$ and lowest amount of calcium content $(0.240 \%)$ recorded from $\mathrm{T}_{1}$ of $\mathrm{CC}$ and $\mathrm{VC}+\mathrm{CC}$ (Table 6). For $\mathrm{T}_{2}$ and $\mathrm{T}_{3}$, calcium content was highest in VC where lowest in CC. It was evident that vermicompost application showed higher calcium content than conventional compost or combination of vermicompost and conventional compost application. In a similar study it was observed that calcium content was higher in vermicompost compared to conventional compost applied in crop production (Singh, 2009). Calcium is a very important mineral in human metabolism, making up about $1-2 \%$ of an adult human's body weight.

\section{Magnesium content}

The highest amount of magnesium content (1.8\%) was recorded from $\mathrm{T}_{3}$ of $\mathrm{VC}$ and lowest amount of magnesium content $(1.07 \%)$ was recorded from $\mathrm{T}_{1}$ of VC (Table 6). It was observed that vermicompost application in $\mathrm{T}_{2}$ and $\mathrm{T}_{3}$ showed higher amount of magnesium content compared with conventional compost or combination of vermicompost and conventional compost in same treatment which encourage enhancement of nutrient content in plant. In a similar study represents the use of vermicompost the best contribution of $\mathrm{Mg}$ macronutrients in the lettuce crop, indicating greater availability of the vermicompost applied crop nutrients in relation to compost (Hernandez et al., 2010) where magnesium has a number of key functions in plants and is necessary for more than 300 chemical reactions in the human body. Researchers have found that even a mild ongoing magnesium deficiency can lead to a significant amount of Chlorosis, drooped leaves (Soetan et al., 2010). Many critical physiological and biochemical processes in plants are adversely affected by $\mathrm{Mg}$ deficiency, leading to impairments in growth and yield (Cakmak and Yazici, 2010).

\section{Potassium content}

The highest amount of potassium content $(11.17 \%)$ was recorded from $\mathrm{T}_{3}$ of $\mathrm{VC}$ and lowest amount of potassium content $(9 \%)$ was recorded from $\mathrm{T}_{1}$ of $\mathrm{CC}$ (Table 6).The study showed that vermicompost application showed higher amount of potassium compared with conventional compost or combination of vermicompost and conventional compost in $\mathrm{T}_{2}$ and $\mathrm{T}_{3}$ which encourage enhancement of nutrient content in vermicompost treated plant. Potassium simulates early growth, increases protein production and vital for persistence and longevity. If $\mathrm{K}$ is deficient or not supplied in adequate amounts, growth is stunted and yields are reduced (Day and Ludeke, 1993). Potassium is an important plant nutrient good for human health as diets high in potassium are associated with improved blood pressure control and improved kidney function. (Mateljan, 2015). The study showed high amount of potassium in every treatment. This might be due to using ash during bed preparation where ash composed high amount of potassium. Potassium is usually present in plants in quantities larger than any other nutrient except nitrogen (Day and Ludeke, 1993).

\section{Sodium content}

Sodium nutrition of plants remains a fascinating and elusive topic but $\mathrm{Na}$ has still not been shown to be essential for majority of higher plants (certain types of $\mathrm{C}_{4}$ plants are an exception) (Subbarao et al., 2003). The highest amount of sodium content $(0.4002 \%)$ was recorded from $\mathrm{T}_{3}$ of $\mathrm{CC}$ and lowest amount of sodium content $(0.1815 \%)$ recorded from $\mathrm{T}_{1}$ of $\mathrm{VC}+\mathrm{CC}$ (Table 6). Among $\mathrm{T}_{2}$ and $\mathrm{T}_{3}$ of all three compost varieties, sodium content was prominent in $\mathrm{CC}$ than $\mathrm{VC}$ and $\mathrm{VC}+\mathrm{CC}$. The study obtained that conventional compost application with higher dose shows higher amount of sodium compared with vermicompost or combination of vermicompost and conventional compost. In a similar study vermicompost showed lower $\mathrm{Na}$ content levels, which is especially important result since the use of organic with high $\mathrm{Na}$ contents must be avoided because the accumulation of salts, especially from $\mathrm{Na}$, represents an important risk for soil salinization and crop toxicity (Hernandez et al., 2010). Sodium concentration at high level $(\geq 100 \mathrm{~m} \mathrm{M})$ is generally results in major growth reduction and/or death of the plants due to the specific ion toxicity of $\mathrm{Na}$ (Greenway and Munns, 1980; Cheeseman, 1988).

\section{Total phosphorus content}

The highest amount of phosphorus content $(0.0077 \%)$ was recorded from $\mathrm{T}_{3}$ of $\mathrm{VC}$ and lowest amount of phosphorus content $(0.0022 \%)$ was recorded from $\mathrm{T}_{1}$ of $\mathrm{VC}+\mathrm{CC}$ (Table 6). The study obtained that vermicompost application in $\mathrm{T}_{2}$ and $\mathrm{T}_{3}$ showed higher amount of phosphorus compared with conventional compost or combination of vermicompost and conventional compost which encourage enhancement of nutrient content in vermicompost treated plant. Phosphorus content enhanced by vermicompost on Amaranthus spinosus production (Uma and Malathi, 2009). Phosphorus lost from agricultural soils can increase the fertility status of natural waters (eutrophication), which can accelerate the growth of algae and other aquatic plants. Adequate phosphorus is needed for the promotion of early root formation and growth. Phosphorus also improves crop quality and is 
necessary for seed formation. Phosphorus is an essential component of bones and teeth. Animals derive their phosphorus needs from plant products and feed supplements (Mullins, 2009). But high phosphorus consumption has been shown to reduce bone mass, loss of renal function, and cardiovascular calcification. Inadequate phosphorus intake rarely results in abnormally low serum phosphorus levels (hypophosphatemia) (Calvo and Uribarri, 2013). As vermicompost application showed moderate phosphorus content in plant, it will be beneficial for public health and environment to practice vermicompost application in crop production.

\section{Sulphur content}

The highest amount of sulphur content $(0.285 \%)$ was recorded from $\mathrm{T}_{3}$ of $\mathrm{VC}$ and lowest amount of sulphur content $(0.177 \%)$ was recorded from $\mathrm{T}_{1}$ of $\mathrm{VC}+\mathrm{CC}$ (Table 6). It was observed from the study, $\mathrm{T}_{2}$ and $\mathrm{T}_{3}$ of vermicompost application showed higher amount of sulphur content compared with conventional aerobic compost or combination of vermicompost and conventional compost in same treatment which encourage enhancement of nutrient content in vermicompost treated plant. So, it was evident that vermicompost application showed higher sulphur content. In a similar study the impact of vermicompost on the yield of maize (Zea mays L.) observed in selected phenological growth stages sulphur content was found to be higher compared to other fertilizers (Kmetova and Kovacik, 2014).

Table 6. Nutrient condition of amaranth by different compost application

\begin{tabular}{|c|c|c|c|c|c|c|c|c|c|}
\hline \multirow[t]{3}{*}{ Parameter } & \multicolumn{9}{|c|}{ Compost $\left(\mathrm{g} \mathrm{m}^{-2}\right)$} \\
\hline & \multicolumn{3}{|c|}{ VC } & \multicolumn{3}{|c|}{$\mathrm{CC}$} & \multicolumn{3}{|c|}{$\mathrm{VC}+\mathrm{CC}$} \\
\hline & 0 & 100 & 150 & 0 & 100 & 150 & 0 & 100 & 150 \\
\hline Nitrogen (\%) & 0.23 & 0.61 & 0.72 & 0.23 & 0.54 & 0.62 & 0.25 & 0.58 & 0.67 \\
\hline Calcium (\%) & 0.481 & 1.443 & 1.683 & 0.240 & 0.561 & 0.641 & 0.240 & 0.561 & 0.802 \\
\hline Magnesium (\%) & 1.070 & 1.702 & 1.800 & 1.265 & 1.362 & 1.362 & 1.313 & 1.459 & 1.508 \\
\hline Potassium (\%) & 10.20 & 11.11 & 11.17 & 9.00 & 10.41 & 10.48 & 9.67 & 10.82 & 10.91 \\
\hline Sodium (\%) & 0.188 & 0.233 & 0.290 & 0.188 & 0.461 & 0.400 & 0.181 & 0.204 & 0.216 \\
\hline Phosphorus (\%) & 0.0039 & 0.0057 & 0.0077 & 0.0027 & 0.0039 & 0.0047 & 0.0022 & 0.0047 & 0.0055 \\
\hline Sulphur (\%) & 0.201 & 0.246 & 0.285 & 0.183 & 0.208 & 0.217 & 0.177 & 0.220 & 0.236 \\
\hline
\end{tabular}

\section{Conclusions}

The results indicated that the application of vermicompost increased plant growth and yield compared with conventional compost or combination of these two composts and integrated effect of all the nutrients present in vermicompost also results in the increased growth of Amaranthus viridis. So it should be recommended for farmers to use vermicompost in crop production which is easily available, nutrient rich, economical and it improves soil physical properties. More research should be carried out to investigate the growth, yield and nutrient content of other crops in

\section{References}

Ayoub, A. T. 1999. Fertilizers and the environment. Nutrient Cycling in Agroecosystems, 55: 117-121.

Baca, M. T.; Fornasier, F. and Nobil, M. D. 1992. Mineralization and humification pathways in two composting processes applied to cotton wastes. Journal of Fermentation and Bioengineering, 74: 179-184.

Blanchart, E.; Albrecht, A.; Alegre, J.; Duboisset, A.; Gilot, C.; Pashanasi, B.; Lavelle, P. and Brussaard. L. 1999. Effects of earthworms on soil structure and physical properties. In: Earthworm management in tropical agro ecosystems. CAB International, Wallingford, UK, 149-172.

Cakmak, I. and Yazici, A. M. 2010. Magnesium: A forgotten element in crop production. Better Crops International, 94(2): 23-25. different season by the application of different compost varieties.

\section{Acknowledgements}

We would like to express our profound gratitude and sincere appreciation to Professor Dr. Md. Zakir Hossen, Department of Agricultural Chemistry, Bangladesh Agricultural University, Mymensingh, for providing laboratory facilities and kind cooperation and consideration and also thankful to Mr. Tanmoy Roy Tusher, Assistant Professor, for his helping hand during the study period.

Calvo, M. S. and Uribarri, J. 2013. Public health impact of dietary phosphorus excess on bone and cardiovascular health in the general population. American Journal of Clinical Nutrition, 98: 6-15.

Castellanos, J. Z.; Uvalle-Bueno, J. X. and AguilarSantelises, Y. A. 2000. Manual de nterpretación de análisis de suelos, aguas agrícolas, plantas ECP. $2^{\text {nd }}$ edition. INIFAP, Chapingo, Mexico.

Cheeseman, J. M. 1988. Mechanisms of salinity tolerance in plants. Plant and Cell Physiology: Oxford Journals, 87: 547-550.

Curran P. J.; Dungan, J. L. and Gholz, H. L. 1990. Exploring the relationship between reflectance red edge and chlorophyll content in slash pine. Tree Physiology, 7: 33-48.

Day, A. D. and Ludeke, K. L. 1993. Plant nutrients in desert environments, potassium as a plant nutrient. Springer, Berlin Heidelberg, pp 49-51. 
Devi, D.; Agarwal, S. K. and Dayal, D. 1998. Response of sunflower (Helianthus annuus L.) to organic manures and fertilizers. Indian Journal of Agronomy, 43(3): 469-473.

Filella I.; Serrano, I.; Serra, J. and Penuelas, J. 1995. Evaluating wheat nitrogen status with canopy reflectance indices and discriminant analysis. Crop Science, 35: 1400-1405.

Grappelli, A.; Galli, E. and U. Tomati. 1987. Earthworm casting effect on Agaricus bisporus fructification. Agrochemica, 21: 457-462.

Greenway, H. and Munns, R. 1980. Mechanisms of salt tolerance in nonhalophytes. Annual Review of Plant Physiology and Plant Molecular Biology, 31: 149190.

Hand, P.; Hayes, W. A.; Frankland, J. C. and Satchell, J. E. 1988. The vermicomposting of cow slurry. Pedobiologia, 31:199-209.

Hernandez, A.; Castillo, H.; Ojeda, D.; Arras, A.; Lopez, J. and Sanchez, E. 2010. Effect of vermicompost and compost on lettuce production. Chilean Journal of Agricultural Research, 70(4):583-589.

Hossain, M. M. 2007. Growth yield and nutrient content of red amaranth as influenced by vermicompost and poultry manure. Department of Agricultural Chemistry, Bangladesh Agricultural University, Mymensingh.

Islam, M. S. 2006. Effects of manures and chemical fertilizers on growth and yield of red amaranth. M.S. Thesis, Department of Agricultural Chemistry, Bangladesh Agricultural University, Mymensingh.

Jahan, F. N.; Shahjalal, A. T. M.; Paul, A. K.; Mehraj, H. and Uddin, A. F. M. J. 2014. Efficacy of vermicompost and conventional compost on growth and yield of cauliflower. Bangladesh Research Publications Journal, 10: 33-38.

Karim, Z. 1997. Accelerating Agricultural Growth in Bangladesh. Paper presented at the seminar on Agricultural Research and Development in Bangladesh.

Kmetova, M. and Kovacik, P. 2014. The impact of vermicompost application on the yield parameters of maize (Zea mays L.) observed in selected phenological growth stages (BBCH-SCALE). Acta Phytotechnology and Zootechnology, 4:100-108.

Mateljan, G. 2015. World's Healthiest Foods. 2nd edition, GMF publishing.

Mullins G. 2009. Phosphorus, Agriculture and the environment. Virginia Cooperative Extention. College of Agriculture and Life Sciences, Virginia Polytechnic Institute and State University. Publication, 424-029.

Ndegwa, P. M. and Thompson, S. A. 2001. Integrating composting and vermicomposting in the treatment of bioconservation of biosolids. Bioresource Technology, 76: 107-112.

Padmavathiamma, P. K..; Li, L. Y. and Kumari, U. R. 2008. An experimental study of Vermi-biowaste composting for agricultural soil improvement. Bioresource Technology, 99: 1972-1681.

Riccardi, M.; Mele, G.; Pulvento, C.; Lavini, A.; D'Andria, R. and Jacobsen, S. E. 2014. Nondestructive evaluation of chlorophyll content in quinoa and amaranth leaves by simple and multiple regression analysis of RGB image components. Photosynthesis Research, 120: 263 272.

Singh, K. 2009. Microbial and Nutritional analysis of vermicompost, aerobic and anaerobic compost. Griffith University, Brisbane, Australia.

Soetan, K. O.; Olaiya, C. O. and Oyewole, O. E. 2010. The importance of mineral elements for humans, domestic animals and plants. A Review of African Journal of Food Science, 5: 200-222.

Sreenivas, C.; Muralidhar, S. and Rao. M. S. 2000. Vermicomposts: a viable component of IPNSS in nitrogen nutrition of ridge gourd. Journal of Agricultural Research, 21(1): 108-113.

Subbarao, G. V.; Ito, O.; Berry, W. L. and Wheeler, R. M. 2003. Sodium a functional plant nutrient. Critical Reviews in Plant Sciences, 22(5): 391-416.

Uma, B. and Malathi, M. 2009. Vermicompost as a soil supplement to improve growth and yield of Amaranthus species. Research J. of Agriculture and Biol. Sciences, 5(6): 1054-1060. 